\title{
Promising Novel Biomarkers in Cardiovascular Diseases
}

\author{
Brigitte Sipos $^{1}$, Peter Jirak ${ }^{1}$, Vera Paar ${ }^{1}$, Richard Rezar ${ }^{1}{ }^{(D}$, Moritz Mirna $^{1}$ (D), Kristen Kopp ${ }^{1}$ (D), Uta C. Hoppe ${ }^{1}$, \\ Alexander E. Berezin ${ }^{2}$ (D) and Michael Lichtenauer $1, * \mathbb{D}$
}

1 Clinic of Internal Medicine II, Department of Cardiology, Paracelsus Medical University of Salzburg, 5020 Salzburg, Austria; b.sipos@salk.at (B.S.); p.jirak@salk.at (P.J.); v.paar@salk.at (V.P.); r.rezar@salk.at (R.R.); m.mirna@salk.at (M.M.); k.kopp@salk.at (K.K.); u.hoppe@salk.at (U.C.H.)

2 Internal Medicine Department, State Medical University, 69000 Zaporozhye, Ukraine; aeberezin@gmail.com

* Correspondence: michael.lichtenauer@chello.at or m.lichtenauer@salk.at

Citation: Sipos, B.; Jirak, P.; Paar, V.; Rezar, R.; Mirna, M.; Kopp, K.;

Hoppe, U.C.; Berezin, A.E.;

Lichtenauer, M. Promising Novel

Biomarkers in Cardiovascular

Diseases. Appl. Sci. 2021, 11, 3654.

https://doi.org/10.3390/app11083654

Academic Editor: Qi-Huang Zheng

Received: 6 March 2021

Accepted: 13 April 2021

Published: 19 April 2021

Publisher's Note: MDPI stays neutral with regard to jurisdictional claims in published maps and institutional affiliations.

\begin{abstract}
Cardiovascular diseases remain the most common causes of death globally, according to the World Health Organization. In recent years, a great number of biomarkers have been investigated, whereas only some have gained value in the diagnosis, prognosis, and risk stratification of different cardiovascular illnesses. As numerous studies have investigated the diagnostic yield of novel biomarkers in various disease entities every year, this review aims to provide an overview of the current status of four promising representatives. In particular, this manuscript refers to soluble suppression of tumorigenicity 2 (sST2), heart-type fatty acid binding protein (H-FABP), growth differentiation factor (GDF-15) and soluble urokinase-type plasminogen activator receptor (suPAR). These markers are of special interest as they are thought to provide an accurate estimate of cardiovascular risk in certain patient populations, especially those with pre-existing diseases, such as obesity or diabetes mellitus. We sought to give an overview of their function, individual diagnostic and predictive value and determination in the laboratory. A review of the literature regarding the aforementioned cardiovascular biomarkers yielded manifold results with respect to their individual diagnostic and prognostic value. Yet, the clinical relevance of these findings remains unclear, warranting further studies to identify their optimal use in clinical routine.
\end{abstract}

Keywords: cardiovascular disease; biomarkers; sST2; H-FABP; GDF-15; suPAR

\section{Introduction}

Cardiovascular diseases (CVD) still account for the majority of global morbidity and mortality and, therefore, represent a significant economic burden not only in economically sovereign countries [1,2]. Thus, increased attention has been paid to biomarkers to better assess the individual risk of developing cardiovascular disease, along with associated complications as well as disease severity. Already established biomarkers, most importantly, brain-type natriuretic peptides (BNPs) and C-reactive protein (CRP), possess well-researched prognostic and diagnostic value. However, they are not universally applicable [3-5] and the influence of concomitant factors (age, renal function, gender etc.) on "traditional" cardiac markers is yet to be fully understood. Recently, the importance of chronic inflammatory processes in cardiovascular disease has been highlighted and consequently focus has been set to cardiac biomarkers indicating inflammation.

The goal in evaluating the use of novel cardiovascular biomarkers is to find solutions for clinical problems, such as early recognition of cardiovascular disease, monitoring of chronic heart failure (HF), prognosis after myocardial infarction or obtaining information about the response to specific therapies. An array of novel cardiac markers are potential candidates for answering these questions; however, whether a single, "loneranger"-cardiovascular biomarker is preferable, or a "multi-marker" approach, where the strengths of different entities are combined to provide an optimal solution in a diverse set of requirements, is not yet known [6]. 
In this review, we sought to gather and summarize the current state of scientific knowledge on the strengths and weaknesses of four different, novel cardiovascular biomarkers (sST2, H-FABP, GDF-15 and suPAR) and their role in identifying inflammatory processes in CVD.

\section{1. sST2}

Soluble suppression of tumorigenicity 2 (sST2) is a cardiac biomarker, which has its main application in HF and acute coronary syndrome (ACS). In these disease entities, it is known to have a prognostic value, while being unaffected by possible confounders such as renal failure, age, sex or anaemia. There are two known isoforms of ST2, namely, the membrane bound ST2L and the soluble form sST2. A known ligand to ST2 is interleukin33 (IL-33). By binding to the ST2L receptor, IL-33 can mediate cardioprotective effects in response to an increase in cardiac stress or injury. While the ST2L-IL-33 interaction is considered as cardioprotective and beneficial, sST2 acts as a decoy receptor for IL33 , attenuating its beneficial effects. Thus, elevated levels of sST2 are associated with higher amounts of cardiac remodelling and cardiac injury. In HF with reduced ejection fraction, sST2 was identified as a potential monitoring parameter with prognostic impact on mortality and long-term survival. In patients with myocardial infarction, sST2 was shown to be significantly elevated, and provided good prognostic value in the acute setting as well as for long-term survival.

Additionally, levels of sST2 were reported to be associated with an increased risk of type 2 diabetes compared to non-diabetic controls [7,8]. Furthermore, levels of sST2 where shown to increase in the presence of left ventricular diastolic dysfunction in diabetic patients [8]. High circulating levels of SST2 also correlate with an increase in fasting plasma glucose [9].

In this regard, another study could show that sST2 levels were predominantly linked to markers associated with diabetes such as insulin resistance or ectopic fat, thus speculating about a potential involvement in inflammatory processes involved in the development of type 2 diabetes [10]. Similarly, Zheyda et al. reported elevated sST2 levels in obese patients, indicating a lower amount of IL-33-mediated beneficial effects in these individuals [11]. Of note, a correlation of sST2 and carotid intima media thickness was reported in a former study [12].

Accordingly, high circulating levels of sST2 were correlated with increased CVD mortality in patients with type 2 diabetes [9]. Jha et al. observed a prognostic impact of sST2 in diabetic patients suffering from ACS [13]. In a study by Alonso et al., sST2 was shown to be independently associated with both all-cause and cardiovascular mortality in diabetes mellitus [14].

The observed correlations between SST2 and diabetes mellitus are assumed to be mainly mediated through its ligand IL-33. IL-33 is involved in the regulation of white adipose tissue (WAT) predominantly mediated via type 2 innate lymphoid cells (ILC2), thereby also increasing caloric expenditure [15]. WAT homeostasis is believed to be disturbed as a consequence of an increase in SST2 and a corresponding decrease of IL-33, promoting a pro-inflammatory state, obesity and thus insulin resistance (IR) and diabetes mellitus.

\section{2. $H-F A B P$}

Heart-type fatty acid binding protein (H-FABP) is a well-known member of a group of proteins (FABPs), which are involved in lipid metabolism and energy homeostasis [16]. $\mathrm{H}-\mathrm{FABP}$ is found in striated muscle cells and is released to the systemic circulation as a consequence of myocardial damage [17]. Several studies found a correlation of H-FABP levels and myocardial apoptosis and decreased cell proliferation [18,19]. Regarding acute cardiovascular events, investigations have shown that H-FABP is an early indicator of myocardial infarction, as well as right heart strain due to pulmonary embolism, for which the 2019 ESC guidelines recommend it as a tool for risk stratification [20-22]. It may also serve as a marker for heart failure due to transient plasma level increases in relation to 
myocardial "wounding", even after short periods of cardiac wall stress [23-25]. Niizeki et al. showed that H-FABP combined with BNP can be used as a reliable tool for risk stratification in hospitalized patients suffering from chronic heart failure. The study did not find a strong correlation between the two markers, demonstrating the different pathophysiological processes, with H-FABP being a result of myocardial damage and BNP a consequence of increased wall strain [26]. Several investigations have shown a prognostic value for the use of H-FABP when it was used to predict adverse events and outcome in patients with heart failure [27-30]. Thus, H-FABP seems not only to be eligible for use as a marker for subclinical myocardial damage, but also as a tool for guidance of clinical management of heart failure and estimation of outcome [30].

\subsection{GDF-15 (Growth Differantiation Factor 15)}

GDF-15 is a dimeric protein and a member of the transforming growth factor beta (TGF- $\beta$ ) family. It was shown to be a useful biomarker in inflammatory processes, CVD, cancer, and kidney injury [31,32].

Kempf et al. used mice with myocardial infarction, HF and pressure overload to show that GDF-15 is important for cardiac cell repair and tissue remodelling [33]. Overall increased serum levels of GDF-15 were predictive for CVD and associated with high all-cause mortality [34].

Kempf et al. also investigated the expression of GDF-15 in participants with ACS or stable angina pectoris, comparing it to the serum levels of NT-proBNP, CRP (C-reactive protein) and troponin. The results demonstrated higher GDF-15 concentrations in patients with ACS than subjects suffering from stable angina pectoris. The patient cohort with stable angina pectoris showed increased levels of GDF-15, but also CRP and NT-proBNP.

To demonstrate the independent diagnostic value of GDF-15, a backward cox regression model was performed and NT-proBNP, troponin, CRP and GDF-15 were all shown to be independently predictive of cardiovascular mortality [35].

Patients with advanced stages of HF showed higher concentrations of GDF-15 and individuals with New York Heart Association (NYHA) class III-IV had higher serum concentrations of GDF-15 than those with less symptoms [36]. In comparison, patients with asymptomatic stage B (ACCF/AHA class) HF showed higher levels of GDF-15 than those in stage A. In summary, GDF-15 could be a predictive biomarker for patients who do not have any limiting symptoms of HF yet [37].

Further correlation of GDF-15 with left ventricular ejection fraction was observed in patients with HF with reduced ejection fraction ( $\mathrm{HFrEF}, \mathrm{LVEF}<40 \%)$. These individuals demonstrated increased concentrations of GDF-15, compared to those with HFmrEF (heart failure with mid-range reduced ejection fraction LVEF $\geq 40-50 \%$ ) or HFpEF (heart failure with preserved ejection fraction, $\mathrm{LVEF}>50 \%$ ) [36].

A main predisposing factor for developing type 2 diabetes and, consequently, CVD, is obesity [38]. Vila et al. found that the GDF-15 serum levels were higher in obese patients. Factors such as age, height, blood pressure and levels of creatinine, triglycerides, glucose, insulin and $\mathrm{HbA} 1 \mathrm{c}$ influence GDF-15 concentrations [39]. Furthermore, Ding et al. showed that women with type 2 diabetes and obesity had higher GDF-15 levels compared to those with normal $\mathrm{HbA1C}$ and/or BMI within normal range [40].

\subsection{SUPAR}

Soluble urokinase plasminogen activator receptor (suPAR) is a membrane-bound protein, which is expressed on vascular endothelium and immunologically active cells. It serves as an inflammatory marker and is also useful for risk stratification concerning development of CVD [41-43]. Elevated suPAR levels reflect subclinical inflammation and are observed in individuals with increased alcohol consumption or smokers [44-46].

SuPAR and C-reactive protein (CRP), both indicators of inflammation and valid biomarkers for CVD processes, do not reflect the same pathophysiologic entities. SuPAR 
has been shown to be a sign of atherosclerosis and endothelial dysfunction; CRP, on the other hand, is associated with body mass index and waist circumference [42,45].

Increased suPAR levels are associated with microalbuminuria in individuals with increased risk of diabetes mellitus type 2 [47]. Heraclides et al. observed a predictive value of suPAR for early detection of diabetes mellitus type 2 in a cohort of 1933 subjects [48]. Furthermore, suPAR was shown to be of prognostic value regarding the outcome of different types of cancer [49,50]. It additionally seems to play a role in the pathogenesis of chronic kidney disease, particularly focal segmental glomerulosclerosis (FSGS) [51].

In an attempt to implement new prognostic biomarkers in routine clinical practice, Schultz et al. found no survival benefit when determining suPAR levels in the emergency department [52]. In patients with sepsis, systemic inflammatory response syndrome, or bacteraemia, suPAR levels were shown to be of prognostic value in estimating disease severity and outcome. However, its diagnostic value is low, as it resembles an unspecific marker of inflammation $[46,53]$. Yet, its prognostic value seems to be superior to other inflammatory biomarkers, such as procalcitonin (PCT), likely due to minimal circadian changes in suPAR levels [54,55].

SuPAR has been shown to be a strong and independent marker of mortality in patients with chronic HF or type 2 diabetes and can also improve the accuracy of risk stratification when combined with traditional measures, such as evaluation of cardiovascular risk factors, coronary artery calcifications, or high-sensitivity CRP [56,57]. Figure 1 provides an overview of different pathological pathways addressed by novel biomarkers.

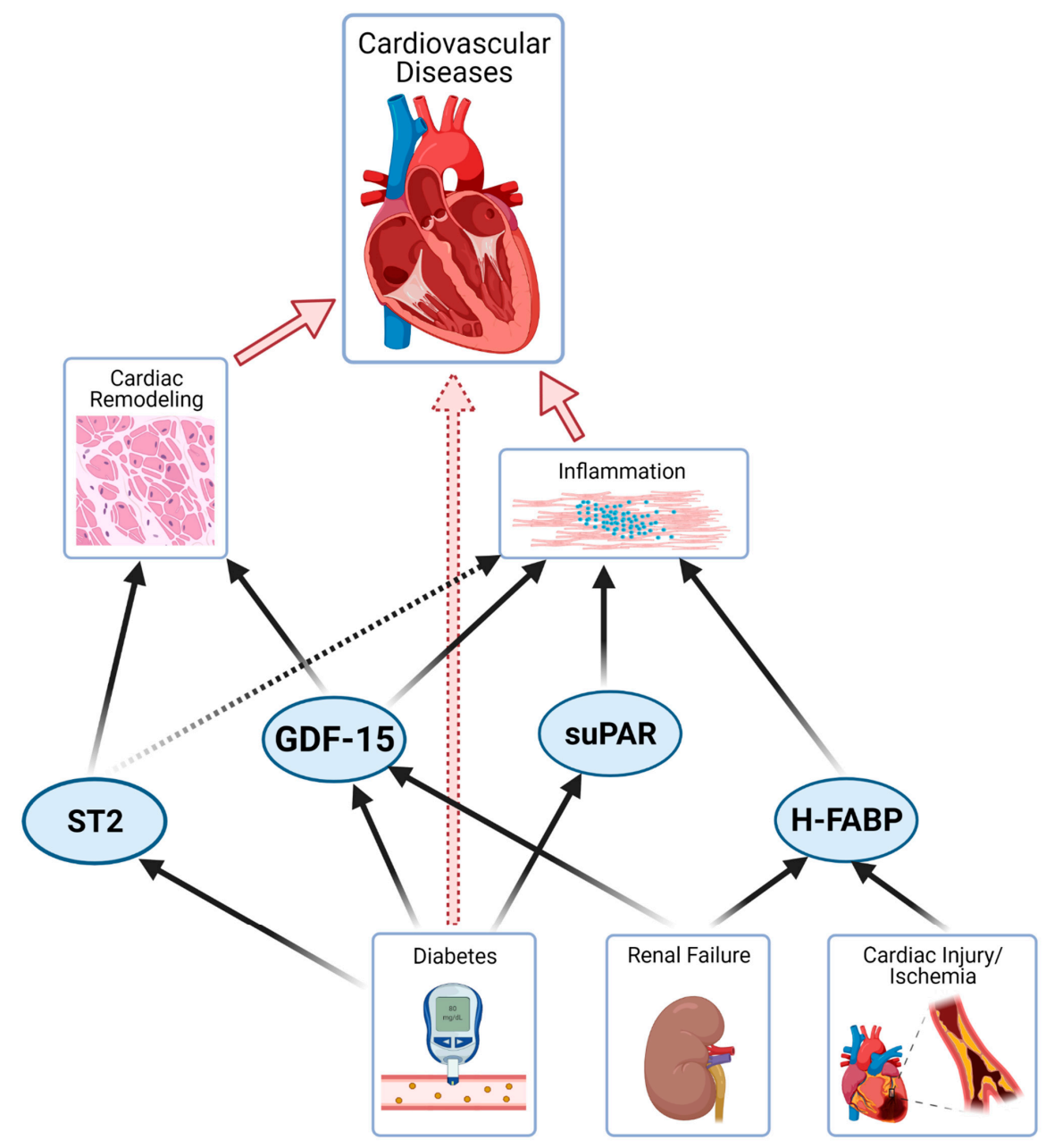

Figure 1. Illustration of novel biomarkers and pathophysiological mechanisms in different organ systems (remodelling, inflammation, calcification, diabetes and renal dysfunction; arrows = strong relationship, dotted arrow $=$ partial relationship). 


\section{5. $c B I N 1$}

Cardiac bridging integrator 1 (cBIN1) is an integral part of cardiomyocyte microtubule anatomy and regulation of calcium currents $[58,59]$. Recent studies have shown an inverse correlation of cBIN1 plasma levels with occurrence and severity of chronic heart failure $[60,61]$. Cardiac bridging integrator 1 score (CS) has been introduced as a tool to use cBIN1 levels for risk stratification among patients who are suffering from or who are at risk of developing chronic heart failure [60,61].

\section{Common Detection Methods for Biomarker Analysis}

As previously mentioned, biomarkers such as sST2, H-FABP, GDF-15, and suPAR, or a combined analysis thereof, may represent a promising tool to support the clinical diagnosis of certain CVD. Therefore, the availability of detection methods to gain reproducible and reliable biomarker concentrations is crucial.

Soluble proteins are secreted into the circulation where they can easily be harvested in whole blood by venous puncture. Serum or plasma samples may then be derived by centrifugation of whole blood at $2000 \mathrm{rpm}$ for approximately $20 \mathrm{~min}$. The samples may be measured directly, or stored at $-80^{\circ} \mathrm{C}$ until further analysis to prevent the degradation of the proteins of interest. Absorbance assays, such as enzyme-linked immunosorbent assay (ELISA) belong to the main standard procedures for soluble biomarker detection. Most of the available ELISA kits for serum or plasma analyses are based on the so-called "Sandwich" ELISA, where a capture antibody binds the antigen in the sample. A colour reaction is achieved by the addition of an appropriate detection antibody in addition to an enzyme that is activated by a 3,3',5,5'-Tetramethylbenzidine (TMB) substrate. The optical density can then be measured with the help of an absorbance reader [62]. Although several manufacturers have attempted to develop an assay that may be used in the clinical setting, only a few ELISA kits have diagnostic grade approval. As biomarker detection using ELISA is a rather time-consuming procedure, different companies have already successfully developed some rapid tests to get reproducible biomarker level results within a couple of minutes [63].

As far as the detection of sST2 is concerned, a large range of ELISA kits from various manufacturers is available. However, most are approved for research use only. The kits from R\&D Systems (Human ST2/IL-33R Quantikine ELISA Kit [9], Human ST2/IL-33R DuoSet ELISA [64]; Minneapolis, MN), and Medical \& Biological Laboratories (MBL) Co, Ltd. (Woburn, MA, USA) [65-67] are most commonly used in research laboratories all over the world. To date, only two assays are available that have the certificate for clinical usage: the highly sensitive Presage Assay (Critical Diagnostics, San Diego, CA, USA) [68-72] and the ASPECT PLUS ST2 Quantitative Rapid Test Assay (Critical Diagnostics, San Diego, CA, USA), which is based on quantification by sandwich monoclonal lateral flow of anticoagulated blood $[63,73,74]$. For the latter, a small amount $(35 \mu \mathrm{L})$ of the patient's serum or plasma is loaded onto an analysis cassette and two drops of a provided buffer are added. The cassette is then analysed using an appropriate reader and results may be obtained within $20 \mathrm{~min}$ [75]. Although all available ELISA kits have been approved for diagnostic or research purposes, studies have revealed large discrepancies in serum or plasma SST2 values among the different kits [76].

Several studies have concluded that H-FABP is a promising and reliable biomarker for the diagnosis of several cardiac diseases, such as acute myocardial infarction (AMI) [77]. As a consequence thereof, several test types and assays haven been developed to determine the biomarker's levels in peripheral blood, as well as in urine. In 1995, Ohkaru et al. developed an immunosorbent technique to assess and quantify H-FABP by ELISA [78], which was the milestone for the development of further ELISA kits which are widely available nowadays: the kits from R\&D Systems (Human FABP3 DuoSet ELISA [79], Minneapolis, MN) and Hycult Biotechnology (Uden, The Netherlands) [80] have great evidence to assess blood $\mathrm{H}-\mathrm{FABP}$ levels in several clinical research projects. As far as the clinical diagnosis of $\mathrm{H}$ FABP is concerned, the Heart FABP (FABP3) Human ELISA kit from BioVendor Laboratory 
Medicine (Modrice, Czech Republic) has successfully gained clinical diagnostic grade. However, besides ELISA other techniques for the quantification of H-FABP levels exist, such as proximity extension analyses (described elsewhere) [81], and latex enhanced turbidimetric immunoassays $[82,83]$. The latter is based on latex particles that are coated with a monoclonal anti H-FABP antibody that bind the appropriate antigen in the sample and agglutinate. Thereafter, the light scattering caused by an increase in particle size is a measure of the H-FABP concentration (HiSens H-FABP turbidimetric immunoassay, HBI, Anyang, Korea) [84]. Randox Laboratories Limited (Crumlin, Co. Antrim, UK) provides a fully automated system that quantifies the protein's level within approximately $15 \mathrm{~min}[85,86]$. In comparison to the results gained by ELISA, immunoturbidimetric assays reveal higher H-FABP levels with a greater area under the curve and superior prognostic information than ELISA [83]. In addition to that, several bedside rapid tests have already been established to provide quantitative results within a short time range: Cardiodetect ${ }^{\circledR}$ from Rennesens $\mathrm{GmbH}$ (Berlin, Germany) was the first H-FABP rapid test worldwide and is based on a chromatographic immunoreaction that detects the protein's level in the patients' whole blood with a threshold of $7 \mathrm{ng} / \mathrm{mL}[87,88]$. Further companies have then seized on this idea to improve the rapid clinical diagnosis of cardiac biomarkers, combining the two most important cardiac biomarkers, H-FABP and troponin I, in one single rapid test cassette. The combined tests are also based on the binding properties of the appropriate antigens with the specific antibodies that are provided on a nitrocellulose membrane (e.g., H-FABP and cTnI Combo Rapid Test Cassette by BioZEK B.V., The Netherlands, or MyoCheck ${ }^{\circledR}$ by Concile $\mathrm{GmbH}$, Germany).

GDF-15 is a highly prominent biomarker in CVD, thus reliable and reproducible test results are crucial for risk stratification and prognosis. Several studies have addressed the measurement of this biomarker using the research kits Quantikine [89-92] and DuoSet [93-96] ELISA from R\&D Systems (Minneapolis, MN). However, some in vitro diagnostic assays for GDF-15 have already been developed, namely GDF-15/MIC-1 Human ELISA from BioVendor Laboratory Medicine (Modrice, Czech Republic) [97-99]. More recently, a relatively new methodology has emerged and already received the CE mark in the European Union. The automated electrochemiluminescence (Elecsys ${ }^{\circledR}$ ) immunoassay by Roche Diagnostics (Basel, Switzerland) is based on a sandwich immunoassay principle that may be performed with $35 \mu \mathrm{L}$ of the patient's blood sample. Two incubation periods of only 9 min with automated washing steps in between make this a straightforward, rapid procedure requiring little personnel effort. The detection of the quantitative signal is achieved by measuring the antigen-antibody complexes via electrochemiluminescence using a cobas e analyser (Roche Diagnostics, Basel, Switzerland) [100-102]. Some studies, such as that of Wollert et al. [103], have compared serum or plasma GDF-15 levels gained by different available research and diagnostic kits. The results showed that GDF-15 concentrations measured by Elecsys assay correlated with those from ELISA. Additionally, it has been shown that the GDF-15 concentrations do not differ significantly in plasma or serum samples, respectively [90].

As for the other biomarkers mentioned, the sandwich ELISA procedure is also the method of choice for the measurement of peripheral suPAR concentrations. The most prominent and widely used kit certainly is the suPARnostic ${ }^{\circledR}$ ELISA by ViroGates (Birkerød, Denmark). The kit is certified for in vitro diagnostics and is therefore valid for clinical use [104]. In contrast to the kits available for research use only, such as the Quantikine [105-107] and DuoSet $[79,93,95]$ ELISA Kits from R\&D Systems, the benefits of suPARnostic ${ }^{\circledR}$ ELISA include the time-to-result ofonly $1.5 \mathrm{~h}$ and the easy handling of the ready-to-use reagents. The blood samples are mixed with provided secondary peroxidase-linked antibodies and are then applied to a pre-coated test plate [108-112]. Additionally, ViroGates has overcome the challenge of generating a rapid test capable of providing peripheral suPAR concentrations within 20 min. The suPARnostic ${ }^{\circledR}$ Quick Triage (ViroGates, Birkerød, Denmark) is a relatively new method which allows the quantification of biomarker levels by the lateral flow principle, not requiring analysis in a diagnostic laboratory. Only a few studies 
have already used this quick test for the analysis of a patient's blood, such as Kumar et al. [113], and Sandrø et al. [114]. Furthermore, suPAR may also be alternatively detected by a turbidimetric assay, which is a rapid latex particle-enhanced immunoassay, called suPARnostic ${ }^{\circledR}$ TurbiLatex (ViroGates, Birkerød, Denmark). Previously, Skovsted et al. have compared plasma suPAR levels obtained by turbidimetric assay on Roche Cobas ${ }^{\circledR}$ 8000 measurement systems, with the results obtained by suPARnostic ${ }^{\circledR}$ ELISA; it was shown that the results gained correlate strongly with those from ELISA analysis and exhibit a high reproducibility. Therefore, suPARnostic ${ }^{\circledR}$ TurbiLatex is a reliable alternative to the relatively time-consuming ELISA procedure to evaluate the plasma's suPAR levels within $10 \min [115]$.

\section{Inflammatory Processes in Cardiovascular Disease}

Atherosclerosis is widely recognized as a product of chronic arterial inflammation. Atheromas, as sites of ongoing cytokine production, are the root cause of major cardiovascular events through rupture and subsequent vessel occlusion [116,117]. Certain cardiovascular biomarkers, such as hs-CRP and suPAR, are indicators of inflammatory activity, and can therefore reflect atherosclerotic processes and give an estimation of cardiovascular risk [104]. Furthermore, sST2, which is part of the IL33-ST2L axis, is an indicator of immune responses, whether due to an exposure to pathogens, death by apoptosis or necrosis, which represents a key part of myocardial infarction [118]. Levels of sST2 can, therefore, reflect the extent of myocardial damage, and predict the outcomes and the length of hospital stay $[6,119]$. Using novel biomarkers has provided us with a more detailed understanding of inflammatory and immunologic processes in CVD. That knowledge could serve as grounds for future treatment strategies that specifically target and possibly attenuate the inflammatory processes involved in atherosclerosis or myocardial damage [120,121].

\section{Multimarker Approach}

While each of the discussed biomarkers reflect pathologic processes with respect to CVD and predisposing conditions, each one has its strengths and weaknesses. While sST2, suPAR and GDF-15, for example, can be significantly elevated in patients suffering from acute myocardial infarction (AMI), levels of sST2 and GDF-15, but not suPAR, correlate with the duration of hospitalization and possibly predict the development of chronic HF after the initial event $[6,119,122]$. Elevated levels of suPAR, on the other hand, correlate with atherosclerosis, (pre-) diabetes and impaired renal function [42,46,51]. SuPAR, therefore, might be a valuable tool in the recognition of risk factors for primary prevention of cardiovascular events. These are only a few examples of specific scopes of application for selected novel cardiovascular biomarkers. A multimarker approach combines various markers and their individual strengths for risk stratification and prediction of outcomes, as well as diagnostic purposes.

\section{Conclusions}

Novel cardiovascular biomarkers, in addition to "traditional" markers (pBNP, hstroponin, CRP) are able to provide additional prognostic information regarding cardiovascular risk in patient populations with certain predisposing conditions, such as diabetes mellitus, renal failure, or obesity. They may also provide a reliable estimation about prognosis in chronic HF and reflect inflammatory processes, such as atherosclerosis and cardiac remodelling after myocardial infarction. Clinical relevance for these findings, however, is yet to be established and might be accomplishable by utilizing a multimarker approach. Concerning this, it is also crucial that reliable and relatively rapid assays for the measurement of circulating biomarkers in the patients' serum or plasma samples are available. However, more clinically oriented studies regarding the usability of most prognostic biomarkers are warranted. 
Author Contributions: Conceptualization, M.L., B.S. and P.J.; resources M.L., B.S. and P.J.; writingoriginal draft preparation, B.S., P.J. and V.P.; writing—review and editing, K.K., M.L., R.R., M.M., A.E.B.; supervision, U.C.H. All authors have read and agreed to the published version of the manuscript.

Funding: This research received no external funding.

Institutional Review Board Statement: Not applicable.

Informed Consent Statement: Not applicable.

Conflicts of Interest: The authors declare no conflict of interest.

\section{References}

1. Mozaffarian, D.; Benjamin, E.J.; Go, A.S.; Arnett, D.K.; Blaha, M.J.; Cushman, M.; de Ferranti, S.; Despres, J.P.; Fullerton, H.J.; Howard, W.J.; et al. Heart disease and stroke statistics-2015 update: A report from the American Heart Association. Circulation 2015, 131, e29-e322. [CrossRef]

2. Gheorghe, A.; Griffiths, U.; Murphy, A.; Legido-Quigley, H.; Lamptey, P.; Perel, P. The economic burden of cardiovascular disease and hypertension in low- and middle-income countries: A systematic review. BMC Public Health 2018, 18, 1-11. [CrossRef] [PubMed]

3. Omland, T.; Sabatine, M.S.; Jablonski, K.A.; Rice, M.M.; Hsia, J.; Wergeland, R.; Landaas, S.; Rouleau, J.L.; Domanski, M.J.; Hall, C.; et al. Prognostic value of B-Type natriuretic peptides in patients with stable coronary artery disease: The PEACE Trial. J. Am. Coll. Cardiol. 2007, 50, 205-214. [CrossRef] [PubMed]

4. $\quad$ Eggers, K.M.; Kempf, T.; Venge, P.; Wallentin, L.; Wollert, K.C.; Lindahl, B. Improving long-term risk prediction in patients with acute chest pain: The Global Registry of Acute Coronary Events (GRACE) risk score is enhanced by selected nonnecrosis biomarkers. Am. Heart J. 2010, 160, 88-94. [CrossRef] [PubMed]

5. Wolsk, E.; Claggett, B.; Pfeffer, M.A.; Diaz, R.; Dickstein, K.; Gerstein, H.C.; Lawson, F.C.; Lewis, E.F.; Maggioni, A.P.; McMurray, J.J.V.; et al. Role of B-Type Natriuretic Peptide and N-Terminal Prohormone BNP as Predictors of Cardiovascular Morbidity and Mortality in Patients with a Recent Coronary Event and Type 2 Diabetes Mellitus. J. Am. Heart Assoc. 2017, 6, e004743. [CrossRef] [PubMed]

6. Schernthaner, C.; Lichtenauer, M.; Wernly, B.; Paar, V.; Pistulli, R.; Rohm, I.; Jung, C.; Figulla, H.-R.; Yilmaz, A.; Cadamuro, J.; et al. Multibiomarker analysis in patients with acute myocardial infarction. Eur. J. Clin. Investig. 2017, 47, 638-648. [CrossRef]

7. Lin, Y.-H.; Zhang, R.-C.; Hou, L.-B.; Wang, K.-J.; Ye, Z.-N.; Huang, T.; Zhang, J.; Chen, X.; Kang, J.-S. Distribution and clinical association of plasma soluble ST2 during the development of type 2 diabetes. Diabetes Res. Clin. Pr. 2016, 118, 140-145. [CrossRef]

8. Fousteris, E.; Melidonis, A.; Panoutsopoulos, G.; Tzirogiannis, K.; Foussas, S.; Theodosis-Georgilas, A.; Tzerefos, S.; Matsagos, S.; Boutati, E.; Economopoulos, T.; et al. Toll/Interleukin-1 receptor member ST2 exhibits higher soluble levels in type 2 diabetes, especially when accompanied with left ventricular diastolic dysfunction. Cardiovasc. Diabetol. 2011, 10, 101. [CrossRef]

9. Cardellini, M.; Rizza, S.; Casagrande, V.; Cardolini, I.; Ballanti, M.; Davato, F.; Porzio, O.; Canale, M.P.; Legramante, J.M.; Mavilio, M.; et al. Soluble ST2 is a biomarker for cardiovascular mortality related to abnormal glucose metabolism in high-risk subjects. Acta Diabetol. 2018, 56, 273-280. [CrossRef]

10. Miller, A.M.; Purves, D.; McConnachie, A.; Asquith, D.L.; Batty, G.D.; Burns, H.; Cavanagh, J.; Ford, I.; McLean, J.S.; Packard, C.J.; et al. Soluble ST2 associates with diabetes but not established cardiovascular risk factors: A new inflammatory pathway of relevance to diabetes? PLoS ONE 2012, 7, e47830. [CrossRef] [PubMed]

11. Zeyda, M.; Wernly, B.; Demyanets, S.; Kaun, C.; Hämmerle, M.; Hantusch, B.; Schranz, M.; Neuhofer, A.; Itariu, B.K.; Keck, M.; et al. Severe obesity increases adipose tissue expression of interleukin-33 and its receptor ST2, both predominantly detectable in endothelial cells of human adipose tissue. Int. J. Obes. 2012, 37, 658-665. [CrossRef]

12. Hu, X.; Zhang, H.; Song, Y.; Yang, Q.; Zhuang, L.; Jin, G.; Zhang, S.; Sun, W.; Shi, Z. Soluble ST2 is associated with increased carotid intima-media thickness in patients with type 2 diabetes mellitus: A case-control study. Medicine 2020, 99, e18940. [CrossRef] [PubMed]

13. Jha, D.; Goenka, L.; Ramamoorthy, T.; Sharma, M.; Dhandapani, V.E.; George, M.; Thilagavathi, R. Prognostic role of soluble ST2 in acute coronary syndrome with diabetes. Eur. J. Clin. Investig. 2018, 48, e12994. [CrossRef] [PubMed]

14. Alonso, N.; Lupón, J.; Barallat, J.; De Antonio, M.; Domingo, M.; Zamora, E.; Moliner, P.; Galán, A.; Santesmases, J.; Pastor, C.; et al. Impact of diabetes on the predictive value of heart failure biomarkers. Cardiovasc. Diabetol. 2016, 15, 1-9. [CrossRef] [PubMed]

15. Schwartz, C.; O'Grady, K.; Lavelle, E.C.; Fallon, P.G. Interleukin 33: An innate alarm for adaptive responses beyond Th2 immunity-emerging roles in obesity, intestinal inflammation, and cancer. Eur. J. Immunol. 2016, 46, 1091-1100. [CrossRef]

16. Chmurzyńska, A. The multigene family of fatty acid-binding proteins (FABPs): Function, structure and polymorphism. J. Appl. Genet. 2006, 47, 39-48. [CrossRef]

17. Liebetrau, C.; Nef, H.M.; Dörr, O.; Gaede, L.; Hoffmann, J.; Hahnel, A.; Rolf, A.; Troidl, C.; Lackner, K.J.; Keller, T.; et al. Release kinetics of early ischaemic biomarkers in a clinical model of acute myocardial infarction. Heart 2014, 100, 652-657. [CrossRef]

18. Tang, M.K.; Kindler, P.M.; Cai, D.Q.; Chow, P.H.; Li, M.; Lee, K.K.H. Heart-type fatty acid binding proteins are upregulated during terminal differentiation of mouse cardiomyocytes, as revealed by proteomic analysis. Cell Tissue Res. 2004, 316, 339-347. [CrossRef] 
19. Wang, S.; Zhou, Y.; Andreyev, O.; Hoyt, R.F.; Singh, A.; Hunt, T.; Horvath, K.A. Overexpression of FABP3 inhibits human bone marrow derived mesenchymal stem cell proliferation but enhances their survival in hypoxia. Exp. Cell Res. 2014, 323, 56-65. [CrossRef]

20. Qian, H.-Y.; Huang, J.; Yang, Y.-J.; Yang, Y.-M.; Li, Z.-Z.; Zhang, J.-M. Heart-type Fatty Acid Binding Protein in the Assessment of Acute Pulmonary Embolism. Am. J. Med Sci. 2016, 352, 557-562. [CrossRef]

21. Schoenenberger, A.W.; Stallone, F.; Walz, B.; Bergner, M.; Twerenbold, R.; Reichlin, T.; Zogg, B.; Jaeger, C.; Erne, P.; Mueller, C. Incremental value of heart-type fatty acid-binding protein in suspected acute myocardial infarction early after symptom onset. Eur. Heart J. Acute Cardiovasc. Care 2015, 5, 185-192. [CrossRef]

22. Konstantinides, S.V.; Meyer, G.; Becattini, C.; Bueno, H.; Geersing, G.J.; Harjola, V.P.; Huisman, M.; Humbert, M.; Jennings, C.S.; Jiminez, D.; et al. 2019 ESC Guidelines for the diagnosis and management of acute pulmonary embolism developed in collaboration with the European Respiratory Society (ERS). Eur. Heart J. 2020, 41, 543-603. [CrossRef] [PubMed]

23. Iida, M.; Yamazaki, M.; Honjo, H.; Kodama, I.; Kamiya, K. Predictive value of heart-type fatty acid-binding protein for left ventricular remodelling and clinical outcome of hypertensive patients with mild-to-moderate aortic valve diseases. J. Hum. Hypertens. 2007, 21, 551-557. [CrossRef] [PubMed]

24. Ye, X.-D.; He, Y.; Wang, S.; Wong, G.T.; Irwin, M.G.; Xia, Z. Heart-type fatty acid binding protein (H-FABP) as a biomarker for acute myocardial injury and long-term post-ischemic prognosis. Acta Pharmacol. Sin. 2018, 39, 1155-1163. [CrossRef]

25. Fischer, T.A.; McNeil, P.L.; Khakee, R.; Finn, P.; Kelly, R.A.; Pfeffer, M.A.; Pfeffer, J.M. Cardiac myocyte membrane wounding in the abruptly pressure-overloaded rat heart under high wall stress. Hypertension 1997, 30, 1041-1046. [CrossRef]

26. Niizeki, T.; Takeishi, Y.; Arimoto, T.; Takahashi, T.; Okuyama, H.; Takabatake, N.; Nozaki, N.; Hirono, O.; Tsunoda, Y.; Shishido, T.; et al. Combination of Heart-Type Fatty Acid Binding Protein and Brain Natriuretic Peptide Can Reliably Risk Stratify Patients Hospitalized for Chronic Heart Failure. Circ. J. 2005, 69, 922-927. [CrossRef]

27. Ho, S.-K.; Wu, Y.-W.; Tseng, W.-K.; Leu, H.-B.; Yin, W.-H.; Lin, T.-H.; Chang, K.-C.; Wang, J.-H.; Yeh, H.-I.; Wu, C.-C.; et al. The prognostic significance of heart-type fatty acid binding protein in patients with stable coronary heart disease. Sci. Rep. 2018, 8, 14410. [CrossRef]

28. Hoffmann, U.; Espeter, F.; Weiß, C.; Ahmad-Nejad, P.; Lang, S.; Brueckmann, M.; Akin, I.; Neumaier, M.; Borggrefe, M.; Behens, M. Ischemic biomarker heart-type fatty acid binding protein (hFABP) in acute heart failure-Diagnostic and prognostic insights compared to NT-proBNP and troponin I. BMC Cardiovasc. Disord. 2015, 15, 50. [CrossRef] [PubMed]

29. Niizeki, T.; Takeishi, Y.; Arimoto, T.; Nozaki, N.; Hirono, O.; Watanabe, T.; Nitobe, J.; Miyashita, T.; Miyamoto, T.; Koyama, Y.; et al. Persistently Increased Serum Concentration of Heart-Type Fatty Acid-Binding Protein Predicts Adverse Clinical Outcomes in Patients With Chronic Heart Failure. Circ. J. 2008, 72, 109-114. [CrossRef]

30. Rezar, R.; Jirak, P.; Gschwandtner, M.; Derler, R.; Felder, T.K.; Haslinger, M.; Kopp, K.; Seelmaier, C.; Granitz, C.; Hoppe, U.C.; et al. Heart-Type Fatty Acid-Binding Protein (H-FABP) and its Role as a Biomarker in Heart Failure: What Do We Know So Far? J. Clin. Med. 2020, 9, 164. [CrossRef] [PubMed]

31. Hennige, A.M.; Staiger, H.; Wicke, C.; Machicao, F.; Fritsche, A.; Häring, H.-U.; Stefan, N. Fetuin-A Induces Cytokine Expression and Suppresses Adiponectin Production. PLoS ONE 2008, 3, e1765. [CrossRef] [PubMed]

32. Nair, V.; Robinson-Cohen, C.; Smith, M.R.; Bellovich, K.A.; Bhat, Z.Y.; Bobadilla, M.; Brosius, F.; De Boer, I.H.; Essioux, L.; Formentini, I.; et al. Growth Differentiation Factor-15 and Risk of CKD Progression. J. Am. Soc. Nephrol. 2017, 28, 2233-2240. [CrossRef]

33. Kempf, T.; Eden, M.; Strelau, J.; Naguib, M.; Willenbockel, C.; Tongers, J.; Heineke, J.; Korlarz, D.; Xu, J.; Molkentin, J.D.; et al. The transforming growth factor-beta superfamily member growth-differentiation factor-15 protects the heart from ischemia/reperfusion injury. Circ. Res. 2006, 98, 351-360. [CrossRef]

34. Tuegel, C.; Katz, R.; Alam, M.; Bhat, Z.; Bellovich, K.; de Boer, I.; Brosius, F.; Gadegbeku, C.; Gipson, D.; Hawkins, J.; et al. GDF-15, Galectin 3, Soluble ST2, and Risk of Mortality and Cardiovascular Events in CKD. Am. J. Kidney Dis. 2018, 72, 519-528. [CrossRef] [PubMed]

35. Kempf, T.; Sinning, J.M.; Quint, A.; Bickel, C.; Sinning, C.; Wild, P.S.; Schnabel, R.; Lubos, E.; Rupperecht, H.J.; Munzel, T.; et al. Growth-differentiation factor-15 for risk stratification in patients with stable and unstable coronary heart disease: Results from the AtheroGene study. Circ. Cardiovasc. Genet. 2009, 2, 286-292. [CrossRef] [PubMed]

36. Li, J.; Cui, Y.; Huang, A.; Li, Q.; Jia, W.; Liu, K.; Qi, X. Additional Diagnostic Value of Growth Differentiation Factor-15 (GDF-15) to N-Terminal B-Type Natriuretic Peptide (NT-proBNP) in Patients with Different Stages of Heart Failure. Med. Sci. Monit. 2018, 24, 4992-4999. [CrossRef]

37. Anand, I.S.; Kempf, T.; Rector, T.S.; Tapken, H.; Allhoff, T.; Jantzen, F.; Kuskowski, M.; Cohn, J.N.; Drexler, H.; Wollert, K.C. Serial measurement of growth-differentiation factor-15 in heart failure: Relation to disease severity and prognosis in the Valsartan Heart Failure Trial. Circulation 2010, 122, 1387-1395. [CrossRef]

38. Mazzone, T.; Chait, A.; Plutzky, J. Cardiovascular disease risk in type 2 diabetes mellitus: Insights from mechanistic studies. Lancet 2008, 371, 1800-1809. [CrossRef]

39. Vila, G.; Riedl, M.; Anderwald, C.; Resl, M.; Handisurya, A.; Clodi, M.; Prager, G.; Ludvik, B.; Krebs, M.; Luger, A. The Relationship between Insulin Resistance and the Cardiovascular Biomarker Growth Differentiation Factor-15 in Obese Patients. Clin. Chem. 2011, 57, 309-316. [CrossRef] 
40. Ding, Q.; Mracek, T.; Gonzalez-Muniesa, P.; Kos, K.; Wilding, J.; Trayhurn, P.; Bing, C. Identification of Macrophage Inhibitory Cytokine-1 in Adipose Tissue and Its Secretion as an Adipokine by Human Adipocytes. Endocrinology 2008, 150, $1688-1696$. [CrossRef]

41. Hodges, G.W.; Bang, C.N.; Wachtell, K.; Eugen-Olsen, J.; Jeppesen, J.L. suPAR: A New Biomarker for Cardiovascular Disease? Can. J. Cardiol. 2015, 31, 1293-1302. [CrossRef]

42. Persson, M.; Östling, G.; Smith, G.; Hamrefors, V.; Melander, O.; Hedblad, B.; Engstrom, G. Soluble urokinase plasminogen activator receptor: A risk factor for carotid plaque, stroke, and coronary artery disease. Stroke 2014, 45, 18-23. [CrossRef]

43. Eugen-Olsen, J.; Andersen, O.; Linneberg, A.; Ladelund, S.; Hansen, T.W.; Langkilde, A.; Petersen, J.; Pielak, T.; Møller, L.N.; Jeppesen, J.; et al. Circulating soluble urokinase plasminogen activator receptor predicts cancer, cardiovascular disease, diabetes and mortality in the general population. J. Intern. Med. 2010, 268, 296-308. [CrossRef]

44. Tuomi, H.; Kultti, J.; Danielsson, J.; Kangastupa, P.; Åkerman, K.; Niemelä, O. Serum soluble urokinase plasminogen activator receptor in alcoholics: Relation to liver disease severity, fibrogenesis, and alcohol use. J. Gastroenterol. Hepatol. 2014, 29, 1991-1995. [CrossRef] [PubMed]

45. Lyngbæk, S.; Sehestedt, T.; Marott, J.L.; Hansen, T.W.; Olsen, M.H.; Andersen, O.; Linneberg, A.; Madsbad, S.; Haugaard, S.B.; Eugen-Olsen, J.; et al. CRP and suPAR are differently related to anthropometry and subclinical organ damage. Int. J. Cardiol. 2013, 167, 781-785. [CrossRef] [PubMed]

46. Backes, Y.; Van Der Sluijs, K.F.; Mackie, D.P.; Tacke, F.; Koch, A.; Tenhunen, J.J.; Schultz, M.J. Usefulness of suPAR as a biological marker in patients with systemic inflammation or infection: A systematic review. Intensiv. Care Med. 2012, 38, 1418-1428. [CrossRef]

47. Guthoff, M.; Wagner, R.; Randrianarisoa, E.; Hatziagelaki, E.; Peter, A.; Häring, H.-U.; Fritsche, A.; Heyne, N. Soluble urokinase receptor (suPAR) predicts microalbuminuria in patients at risk for type 2 diabetes mellitus. Sci. Rep. 2017, 7, 40627. [CrossRef]

48. Heraclides, A.; Jensen, T.M.; Rasmussen, S.S.; Eugen-Olsen, J.; Haugaard, S.B.; Borch-Johnsen, K.; Sandbæk, A.; Lauritzen, T.; Witte, D.R. The pro-inflammatory biomarker soluble urokinase plasminogen activator receptor (suPAR) is associated with incident type 2 diabetes among overweight but not obese individuals with impaired glucose regulation: Effect modification by smoking and body weight status. Diabetologia 2013, 56, 1542-1546. [CrossRef] [PubMed]

49. Stephens, R.W.; Nielsen, H.J.; Christensen, I.J.; Thorlacius-Ussing, O.; Sørensen, S.; Danø, K.; Brünner, N. Plasma urokinase receptor levels in patients with colorectal cancer: Relationship to prognosis. J. Natl. Cancer Inst. 1999, 91, 869-874. [CrossRef] [PubMed]

50. Brünner, N.; Nielsen, H.J.; Hamers, M.; Christensen, I.J.; Thorlacius-Ussing, O.; Stephens, R.W. The urokinase plasminogen activator receptor in blood from healthy individuals and patients with cancer. APMIS 1999, 107, 160-167. [CrossRef] [PubMed]

51. Zeier, M.; Reiser, J. suPAR and chronic kidney disease-A podocyte story. Pflugers Arch. 2017, 469, 1017-1020. [CrossRef] [PubMed]

52. Schultz, M.; Rasmussen, L.J.H.; Andersen, M.H.; Stefansson, J.S.; Falkentoft, A.C.; Alstrup, M.; Sandø, A.; Holle, S.L.K.; Meyer, J.; Törnkvist, P.B.S.; et al. Use of the prognostic biomarker suPAR in the emergency department improves risk stratification but has no effect on mortality: A cluster-randomized clinical trial (TRIAGE III). Scand. J. Trauma Resusc. Emerg. Med. 2018, 26, 69. [CrossRef] [PubMed]

53. Koch, A.; Voigt, S.; Kruschinski, C.; Sanson, E.; Dückers, H.; Horn, A.; Yagmur, E.; Zimmermann, H.; Trautwein, C.; Tacke, F. Circulating soluble urokinase plasminogen activator receptor is stably elevated during the first week of treatment in the intensive care unit and predicts mortality in critically ill patients. Crit. Care 2011, 15, R63. [CrossRef]

54. Florquin, S.; Berg, J.G.V.D.; Olszyna, D.P.; Claessen, N.; Opal, S.M.; Weening, J.J.; Van Der Poll, T. Release of urokinase plasminogen activator receptor during urosepsis and endotoxemia. Kidney Int. 2001, 59. [CrossRef] [PubMed]

55. Sier, C.F.; Sidenius, N.; Mariani, A.; Aletti, G.; Agape, V.; Ferrari, A.; Casetta, G.; Stephens, R.W.; Brünner, N.; Blasi, F. Presence of urokinase-type plasminogen activator receptor in urine of cancer patients and its possible clinical relevance. Lab. Investig. 1999, 79, 717-722.

56. Koller, L.; Stojkovic, S.; Richter, B.; Sulzgruber, P.; Potolidis, C.; Liebhart, F.; Mörtl, D.; Berger, R.; Goliasch, G.; Wojta, J.; et al. Soluble Urokinase-Type Plasminogen Activator Receptor Improves Risk Prediction in Patients with Chronic Heart Failure. JACC: Heart Fail. 2017, 5, 268-277. [CrossRef]

57. Hayek, S.S.; Divers, J.; Raad, M.; Xu, J.; Bowden, D.W.; Tracy, M.; Reiser, J.; Freedman, B.I. Predicting Mortality in African Americans With Type 2 Diabetes Mellitus: Soluble Urokinase Plasminogen Activator Receptor, Coronary Artery Calcium, and High-Sensitivity C-Reactive Protein. J. Am. Heart Assoc. 2018, 7. [CrossRef]

58. Hong, T.; Yang, H.; Zhang, S.-S.; Cho, H.C.; Kalashnikova, M.; Sun, B.; Zhang, H.; Bhargava, A.; Grabe, M.; Olgin, J.; et al. Cardiac BIN1 folds T-tubule membrane, controlling ion flux and limiting arrhythmia. Nat. Med. 2014, 20, 624-632. [CrossRef]

59. Hong, T.; Shaw, R.M. Cardiac T-Tubule Microanatomy and Function. Physiol. Rev. 2017, 97, 227-252. [CrossRef]

60. Nikolova, A.P.; Hitzeman, T.C.; Baum, R.; Caldaruse, A.-M.; Agvanian, S.; Xie, Y.; Geft, D.R.; Chang, D.H.; Moriguchi, J.D.; Hage, A.; et al. Association of a Novel Diagnostic Biomarker, the Plasma Cardiac Bridging Integrator 1 Score, With Heart Failure with Preserved Ejection Fraction and Cardiovascular Hospitalization. JAMA Cardiol. 2018, 3, 1206-1210. [CrossRef]

61. Hitzeman, T.C.; Xie, Y.; Zadikany, R.H.; Nikolova, A.P.; Baum, R.; Caldaruse, A.-M.; Agvanian, S.; Melmed, G.Y.; McGovern, D.P.B.; Geft, D.R.; et al. cBIN1 Score (CS) Identifies Ambulatory HFrEF Patients and Predicts Cardiovascular Events. Front. Physiol. 2020, 11, 503. [CrossRef] 
62. Aydin, S. A short history, principles, and types of ELISA, and our laboratory experience with peptide/protein analyses using ELISA. Peptides 2015, 72, 4-15. [CrossRef] [PubMed]

63. Dieplinger, B.; Egger, M.; Gegenhuber, A.; Haltmayer, M.; Mueller, T. Analytical and clinical evaluation of a rapid quantitative lateral flow immunoassay for measurement of soluble ST2 in human plasma. Clin. Chim. Acta 2015, 451, 310-315. [CrossRef] [PubMed]

64. Wang, Y.; Tan, X.; Gao, H.; Yuan, H.; Hu, R.; Jia, L.; Zhu, J.; Sun, L.; Zhang, H.; Huang, L.; et al. Magnitude of Soluble ST2 as a Novel Biomarker for Acute Aortic Dissection. Circulation 2018, 137, 259-269. [CrossRef] [PubMed]

65. O'Donoghue, M.L.; Morrow, D.A.; Cannon, C.P.; Jarolim, P.; Desai, N.R.; Sherwood, M.W.; Murphy, S.A.; Gerszten, R.E.; Sabatine, M.S. Multimarker Risk Stratification in Patients with Acute Myocardial Infarction. J. Am. Heart Assoc. 2016, 5, e002586. [CrossRef]

66. Brown, A.M.; Wu, A.H.; Clopton, P.; Robey, J.L.; Hollander, J.E. ST2 in Emergency Department Chest Pain Patients with Potential Acute Coronary Syndromes. Ann. Emerg. Med. 2007, 50, 153-158.e1. [CrossRef] [PubMed]

67. Bartunek, J.; Delrue, L.; Van Durme, F.; Muller, O.; Casselman, F.; De Wiest, B.; Croes, R.; Verstreken, S.; Goethals, M.; de Raedt, H.; et al. Nonmyocardial Production of ST2 Protein in Human Hypertrophy and Failure Is Related to Diastolic Load. J. Am. Coll. Cardiol. 2008, 52, 2166-2174. [CrossRef] [PubMed]

68. McCarthy, C.P.; Januzzi, J.L. Soluble ST2 in Heart Failure. Heart Fail. Clin. 2018, 14, 41-48. [CrossRef]

69. Broch, K.; Leren, I.S.; Saberniak, J.; Ueland, T.; Edvardsen, T.; Gullestad, L.; Haugaa, K.H. Soluble ST2 is associated with disease severity in arrhythmogenic right ventricular cardiomyopathy. Biomarkers 2017, 22, 367-371. [CrossRef]

70. Liu, X.; Hu, Y.; Huang, W.; Zhang, G.; Cao, S.; Yan, X.; Li, L.; Zhang, L.; Zheng, X. Soluble ST2 for Prediction of Clinical Outcomes in Patients with ST-Segment Elevation Myocardial Infarction Receiving Primary PCI. Int. Heart J. 2019, 60, 19-26. [CrossRef]

71. Morello, F.; Bartalucci, A.; Bironzo, M.; Santoro, M.; Pivetta, E.; Ianniello, A.; Rumbolo, F.; Mengozzi, G.; Lupia, E. Prospective diagnostic accuracy study of plasma soluble ST2 for diagnosis of acute aortic syndromes. Sci. Rep. 2020, 10, 1-10. [CrossRef]

72. O'Meara, E.; Prescott, M.F.; Claggett, B.; Rouleau, J.L.; Chiang, L.-M.; Solomon, S.D.; Packer, M.; McMurray, J.J.; Zile, M.R. Independent Prognostic Value of Serum Soluble ST2 Measurements in Patients with Heart Failure and a Reduced Ejection Fraction in the PARADIGM-HF Trial (Prospective Comparison of ARNI With ACEI to Determine Impact on Global Mortality and Morbidity in Heart Failure). Circ. Heart Fail. 2018, 11, e004446. [CrossRef] [PubMed]

73. Gruson, D.; Ferracin, B.; Ahn, S.A.; Rousseau, M.F. Testing for Soluble ST2 in Heart Failure Patients: Reliability of a Point of Care Method. Clin. Lab. 2017, 63, 141-145. [CrossRef] [PubMed]

74. Okar, S.; Kaypakli, O.; Şahin, D.Y.; Koç, M. Fibrosis Marker Soluble ST2 Predicts Atrial Fibrillation Recurrence after Cryoballoon Catheter Ablation of Nonvalvular Paroxysmal Atrial Fibrillation. Korean Circ. J. 2018, 48, 920-929. [CrossRef]

75. Hartopo, A.B.; Sukmasari, I.; Puspitawati, I. The Utility of Point of Care Test for Soluble ST2 in Predicting Adverse Cardiac Events during Acute Care of ST-Segment Elevation Myocardial Infarction. Cardiol. Res. Pr. 2018, 2018, 1-9. [CrossRef]

76. Mueller, T.; Jaffe, A.S. Soluble ST2—Analytical considerations. Am. J. Cardiol. 2015, 115 (Suppl. S7), 8B-21B. [CrossRef]

77. Xie, P.-Y.; Li, Y.-P.; Chan, C.P.-Y.; Cheung, K.-Y.; Cautherley, G.W.H.; Renneberg, R. A One-Step Immunotest for Rapid Detection of Heart-Type Fatty Acid-Binding Protein in Patients with Acute Coronary Syndromes. J. Immunoass. Immunochem. 2009, 31 , 24-32. [CrossRef]

78. Ohkaru, Y.; Asayama, K.; Ishii, H.; Nishimura, S.; Sunahara, N.; Tanaka, T.; Kawamura, K. Development of a sandwich enzymelinked immunosorbent assay for the determination of human heart type fatty acid-binding protein in plasma and urine by using two different monoclonal antibodies specific for human heart fatty acid-binding protein. J. Immunol. Methods 1995, 178, 99-111. [CrossRef]

79. Jirak, P.; Pistulli, R.; Lichtenauer, M.; Wernly, B.; Paar, V.; Motloch, L.J.; Rezar, R.; Jung, C.; Hoppe, U.C.; Schulze, P.C.; et al. Expression of the Novel Cardiac Biomarkers sST2, GDF-15, suPAR, and H-FABP in HFpEF Patients Compared to ICM, DCM, and Controls. J. Clin. Med. 2020, 9, 1130. [CrossRef]

80. Cubranic, Z.; Madzar, Z.; Matijevic, S.; Dvornik, S.; Fisic, E.; Tomulic, V.; Kunisek, J.; Laskarin, G.; Kardum, I.; Zaputovic, L. Diagnostic accuracy of heart fatty acid binding protein (H-FABP) and glycogen phosphorylase isoenzyme BB (GPBB) in diagnosis of acute myocardial infarction in patients with acute coronary syndrome. Biochem. Med. 2012, 22, 225-236. [CrossRef]

81. Van den Bosch, E.; Bossers, S.S.M.; Kamphuis, V.P.; Boersma, E.; Roos-Hesselink, J.W.; Breur, J.M.P.J.; Ten Harkel, A.D.J.; Kapusta, L.; Bartelds, B.; Roest, A.A.W.; et al. Associations Between Blood Biomarkers, Cardiac Function, and Adverse Outcome in a Young Fontan Cohort. J. Am. Heart Assoc. 2021, 10, e015022. [CrossRef]

82. Moon, M.-G.; Yoon, C.-H.; Lee, K.; Kang, S.-H.; Youn, T.-J.; Chae, I.-H. Evaluation of Heart-type Fatty Acid-binding Protein in Early Diagnosis of Acute Myocardial Infarction. J. Korean Med. Sci. 2021, 36, e61. [CrossRef] [PubMed]

83. Tschepe, M.; Seeber, V.; Zwiener, I.; Kuhnert, K.; Schäfer, K.; Hasenfuß, G.; Konstantinides, S.; Lankeit, M.; Dellas, C. A novel H-FABP assay and a fast prognostic score for risk assessment of normotensive pulmonary embolism. Thromb. Haemost. 2014, 111, 996-1003. [CrossRef] [PubMed]

84. Kim, Y.; Kim, H.; Kim, S.Y.; Lee, H.K.; Kwon, H.J.; Kim, Y.G.; Lee, J.; Kim, H.M.; So, B.H. Automated heart-type fatty acid-binding protein assay for the early diagnosis of acute myocardial infarction. Am. J. Clin. Pathol. 2010, 134, 157-162. [CrossRef] [PubMed]

85. Kavsak, P.A.; Ainsworth, C.; Arnold, D.M.; Scott, T.; Clark, L.; Ivica, J.; Mackett, K.; Whitlock, R.; Worster, A. The potential role of a turbidimetric heart-type fatty acid-binding protein assay to aid in the interpretation of persistently elevated, non-changing, cardiac troponin I concentrations. Clin. Biochem. 2018, 58, 53-59. [CrossRef] [PubMed] 
86. Ruff, C.T.; Bonaca, M.P.; Kosowsky, J.M.; Conrad, M.J.; Murphy, S.A.; Jarolim, P.; Donahoe, S.M.; O’Donoghue, M.L.; Morrow, D.A. Evaluation of the diagnostic performance of heart-type fatty acid binding protein in the BWH-TIMI ED chest pain study. J. Thromb. Thrombolys. 2013, 36, 361-367. [CrossRef] [PubMed]

87. Bruins Slot, M.H.; Rutten, F.H.; van der Heijden, G.J.; Doevendans, P.A.; Mast, E.G.; Bredero, A.C.; van der Spoel, O.P.; Glatz, J.F.C.; Hoes, A.W. Diagnostic value of a heart-type fatty acid-binding protein (H-FABP) bedside test in suspected acute coronary syndrome in primary care. Int. J. Cardiol. 2013, 168, 1485-1489. [CrossRef]

88. Liang, Y.; Chan, C.P.Y.; Cheung, K.-Y.; Cautherley, G.W.H.; Glatz, J.F.C.; Renneberg, R.; Zhu, J. Cardiodetect Rapid Test for the Diagnosis of Early Acute Myocardial Infarction. J. Immunoass. Immunochem. 2011, 32, 342-352. [CrossRef]

89. Bettencourt, P.; Ferreira-Coimbra, J.; Rodrigues, P.; Marques, P.; Moreira, H.; Pinto, M.J.; Guimarães, J.T.; Lourenço, P. Towards a multi-marker prognostic strategy in acute heart failure: A role for GDF-15. ESC Heart Fail. 2018, 5, 1017-1022. [CrossRef]

90. Wollert, K.C.; Kempf, T.; Wallentin, L. Growth Differentiation Factor 15 as a Biomarker in Cardiovascular Disease. Clin. Chem. 2017, 63, 140-151. [CrossRef]

91. Kahli, A.; Guenancia, C.; Zeller, M.; Grosjean, S.; Stamboul, K.; Rochette, L.; Girard, C.; Vergely, C. Growth Differentiation Factor-15 (GDF-15) Levels Are Associated with Cardiac and Renal Injury in Patients Undergoing Coronary Artery Bypass Grafting with Cardiopulmonary Bypass. PLoS ONE 2014, 9, e105759. [CrossRef] [PubMed]

92. Benes, J.; Kotrc, M.; Wohlfahrt, P.; Conrad, M.J.; Franekova, J.; Jabor, A.; Lupinek, P.; Kautzner, J.; Melenovsky, V.; Jarolim, P. The Role of GDF-15 in Heart Failure Patients with Chronic Kidney Disease. Can. J. Cardiol. 2019, 35, 462-470. [CrossRef] [PubMed]

93. Dalos, D.; Spinka, G.; Schneider, M.; Wernly, B.; Paar, V.; Hoppe, U.; Litschauer, B.; Strametz-Juranek, J.; Sponder, M. New Cardiovascular Biomarkers in Ischemic Heart Disease-GDF-15, A Probable Predictor for Ejection Fraction. J. Clin. Med. 2019, 8, 924. [CrossRef]

94. Mirna, M.; Rohm, I.; Jirak, P.; Wernly, B.; Bäz, L.; Paar, V.; Kretzschmar, D.; Hoppe, U.C.; Schulze, P.C.; Lichtenauer, M.; et al. Analysis of Novel Cardiovascular Biomarkers in Patients with Pulmonary Hypertension (PH). Heart Lung Circ. 2020, 29, 337-344. [CrossRef] [PubMed]

95. Jirak, P.; Fejzic, D.; Paar, V.; Wernly, B.; Pistulli, R.; Rohm, I.; Jung, C.; Hoppe, U.C.; Schulze, P.C.; Lichtenauer, M.; et al. Influences of Ivabradine treatment on serum levels of cardiac biomarkers sST2, GDF-15, suPAR and H-FABP in patients with chronic heart failure. Acta Pharmacol. Sin. 2017, 39, 1189-1196. [CrossRef]

96. Lichtenauer, M.; Jirak, P.; Wernly, B.; Paar, V.; Rohm, I.; Jung, C.; Schernthaner, C.; Kraus, J.; Motloch, L.J.; Yilmaz, A.; et al. A comparative analysis of novel cardiovascular biomarkers in patients with chronic heart failure. Eur. J. Intern. Med. 2017, 44, 31-38. [CrossRef]

97. Arslan, D.; Cihan, T.; Kose, D.; Vatansev, H.; Cimen, D.; Koksal, Y.; Oran, B.; Akyurek, F. Growth-differentiation factor-15 and tissue doppler imaging in detection of asymptomatic anthracycline cardiomyopathy in childhood cancer survivors. Clin. Biochem. 2013, 46, 1239-1243. [CrossRef]

98. Izumiya, Y.; Hanatani, S.; Kimura, Y.; Takashio, S.; Yamamoto, E.; Kusaka, H.; Tokitsu, T.; Rokutanda, T.; Araki, S.; Tsujita, K.; et al. Growth Differentiation Factor-15 Is a Useful Prognostic Marker in Patients with Heart Failure With Preserved Ejection Fraction. Can. J. Cardiol. 2014, 30, 338-344. [CrossRef]

99. Montoro-García, S.; Hernández-Romero, D.; Jover, E.; García-Honrubia, A.; Vilchez, J.A.; Casas, T.; Martínez, P.; Climent, V.; Caballero, L.; Valdés, M.; et al. Growth differentiation factor-15, a novel biomarker related with disease severity in patients with hypertrophic cardiomyopathy. Eur. J. Intern. Med. 2012, 23, 169-174. [CrossRef]

100. Zelniker, T.A.; Jarolim, P.; Silverman, M.G.; Bohula, E.A.; Park, J.-G.; Bonaca, M.P.; Scirica, B.M.; Morrow, D.A. Prognostic role of GDF-15 across the spectrum of clinical risk in patients with NSTE-ACS. Clin. Chem. Lab. Med. 2019, 57, 1084-1092. [CrossRef]

101. Santema, B.T.; Chan, M.M.Y.; Tromp, J.; Dokter, M.; van der Wal, H.H.; Emmens, J.E.; Takens, J.; Samani, N.J.; Ng, L.L.; Lang, C.C.; et al. The influence of atrial fibrillation on the levels of NT-proBNP versus GDF-15 in patients with heart failure. Clin. Res. Cardiol. 2020, 109, 331-338. [CrossRef]

102. Kuster, N.; Huet, F.; Dupuy, A.M.; Akodad, M.; Battistella, P.; Agullo, A.; Leclercq, F.; Kalmanovich, E.; Meilhac, A.; Aguilhon, S.; et al. Multimarker approach including CRP, sST2 and GDF-15 for prognostic stratification in stable heart failure. ESC Heart Fail. 2020, 7, 2230-2239. [CrossRef]

103. Wollert, K.C.; Kempf, T.; Giannitsis, E.; Bertsch, T.; Braun, S.L.; Maier, H.; Reim, M.; Christenson, R.H. An Automated Assay for Growth Differentiation Factor 15. J. Appl. Lab. Med. 2017, 1, 510-521. [CrossRef]

104. Diederichsen, M.Z.; Diederichsen, S.Z.; Mickley, H.; Steffensen, F.H.; Lambrechtsen, J.; Sand, N.P.R.; Christensen, K.L.; Olsen, M.H.; Diederichsen, A.; Grønhøj, M.H. Prognostic value of suPAR and hs-CRP on cardiovascular disease. Atherosclerosis 2018, 271, 245-251. [CrossRef] [PubMed]

105. Wu, W.; Cui, Y.; Hu, J.; Liao, R.; Li, S.; Mo, L.; Xu, L.; Chen, Y.; Lian, Z.; Tian, X.; et al. Soluble Urokinase Plasminogen Activator Receptor is Associated with Coronary Artery Calcification and Cardiovascular Disease in Patients Undergoing Hemodialysis. Kidney Blood Press. Res. 2018, 43, 664-672. [CrossRef]

106. Torino, C.; Pizzini, P.; Cutrupi, S.; Postorino, M.; Tripepi, G.; Mallamaci, F.; Reiser, J.; Zoccali, C.; Alati, G.; Barreca, E.; et al. Soluble Urokinase Plasminogen Activator Receptor (suPAR) and All-Cause and Cardiovascular Mortality in Diverse Hemodialysis Patients. Kidney Int. Rep. 2018, 3, 1100-1109. [CrossRef] 
107. Meijers, B.; Poesen, R.; Claes, K.; Dietrich, R.; Bammens, B.; Sprangers, B.; Naesens, M.; Storr, M.; Kuypers, D.; Evenepoel, P. Soluble urokinase receptor is a biomarker of cardiovascular disease in chronic kidney disease. Kidney Int. 2015, 87, 210-216. [CrossRef] [PubMed]

108. Hodges, G.; Lyngbæk, S.; Selmer, C.; Ahlehoff, O.; Theilade, S.; Sehestedt, T.B.; Abildgaard, U.; Eugen-Olsen, J.; Galløe, A.M.; Hansen, P.R.; et al. SuPAR is associated with death and adverse cardiovascular outcomes in patients with suspected coronary artery disease. Scand. Cardiovasc. J. 2020, 54, 339-345. [CrossRef] [PubMed]

109. Hodges, G.W.; Bang, C.N.; Eugen-Olsen, J.; Olsen, M.H.; Boman, K.; Ray, S.; Kesäniemi, A.Y.; Jeppesen, J.L.; Wachtell, K. SuPAR predicts postoperative complications and mortality in patients with asymptomatic aortic stenosis. Open Heart 2018, 5, e000743. [CrossRef]

110. Theilade, S.; Rossing, P.; Eugen-Olsen, J.; Jensen, J.S.; Jensen, M.T. suPAR level is associated with myocardial impairment assessed with advanced echocardiography in patients with type 1 diabetes with normal ejection fraction and without known heart disease or end-stage renal disease. Eur. J. Endocrinol. 2016, 174, 745-753. [CrossRef]

111. Hodges, G.W.; Bang, C.N.; Eugen-Olsen, J.; Olsen, M.H.; Boman, K.; Ray, S.; Gohlke-Bärwolf, C.; Kesäniemi, Y.A.; Jeppesen, J.L.; Wachtell, K. SuPAR Predicts Cardiovascular Events and Mortality in Patients with Asymptomatic Aortic Stenosis. Can. J. Cardiol. 2016, 32, 1462-1469. [CrossRef]

112. Isola, G.; Polizzi, A.; Alibrandi, A.; Williams, R.C.; Leonardi, R. Independent impact of periodontitis and cardiovascular disease on elevated soluble urokinase-type plasminogen activator receptor (suPAR) levels. J. Periodontol. 2020. [CrossRef] [PubMed]

113. Kumar, P.; Kakar, A.; Gogia, A.; Waziri, N. Evaluation of soluble urokinase-type plasminogen activator receptor (suPAR) quick test for triage in the emergency department. J. Fam. Med. Prim. Care 2019, 8, 3871-3875. [CrossRef] [PubMed]

114. Sandø, A.; Schultz, M.; Eugen-Olsen, J.; Rasmussen, L.S.; Køber, L.; Kjøller, E.; Jensen, B.N.; Ravn, L.; Lange, T.; Iversen, K. Introduction of a prognostic biomarker to strengthen risk stratification of acutely admitted patients: Rationale and design of the TRIAGE III cluster randomized interventional trial. Scand. J. Trauma Resusc. Emerg. Med. 2016, 24, 1-7. [CrossRef] [PubMed]

115. Skovsted, T.A.; Petersen, E.R.B.; Fruekilde, M.-B.; Pedersen, A.K.; Pielak, T.; Eugen-Olsen, J. Validation of suPAR turbidimetric assay on Cobas ${ }^{\circledR}$ (c502 and c702) and comparison to suPAR ELISA. Scand. J. Clin. Lab. Investig. 2020, 80, 327-335. [CrossRef]

116. Libby, P.; Ridker, P.M.; Hansson, G.K. Inflammation in Atherosclerosis: From Pathophysiology to Practice. J. Am. Coll. Cardiol. 2009, 54, 2129-2138. [CrossRef]

117. Figueroa, A.L.; Abdelbaky, A.; Truong, Q.A.; Corsini, E.; MacNabb, M.H.; Lavender, Z.R.; Lawler, M.A.; Grinspoon, S.K.; Brady, T.J.; Nasir, K.; et al. Measurement of Arterial Activity on Routine FDG PET/CT Images Improves Prediction of Risk of Future CV Events. JACC Cardiovasc. Imaging 2013, 6, 1250-1259. [CrossRef]

118. Dieplinger, B.; Mueller, T. Soluble ST2 in heart failure. Clin. Chim. Acta 2015, 443, 57-70. [CrossRef]

119. Shimpo, M.; Morrow, D.A.; Weinberg, E.O.; Sabatine, M.S.; Murphy, S.A.; Antman, E.M.; Lee, R.T. Serum Levels of the Interleukin1 Receptor Family Member ST2 Predict Mortality and Clinical Outcome in Acute Myocardial Infarction. Circulation 2004, 109, 2186-2190. [CrossRef]

120. Geovanini, G.R.; Libby, P. Atherosclerosis and inflammation: Overview and updates. Clin. Sci. 2018, 132, 1243-1252. [CrossRef]

121. Newby, L.K. Inflammation as a Treatment Target after Acute Myocardial Infarction. N. Engl. J. Med. 2019, $381,2562-2563$. [CrossRef] [PubMed]

122. Wollert, K.C.; Kempf, T.; Lagerqvist, B.; Lindahl, B.; Olofsson, S.; Allhoff, T.; Peter, T.; Siegbahn, A.; Venge, P.; Drexler, H.; et al. Growth Differentiation Factor 15 for Risk Stratification and Selection of an Invasive Treatment Strategy in Non-ST-Elevation Acute Coronary Syndrome. Circulation 2007, 116, 1540-1548. [CrossRef] [PubMed] 